\title{
THE EVOLUTION OF TEXT MESSAGING: AN EXPANDED REVIEW OF INFLUENCING VARIABLES OVER TIME
}

\author{
Alan Peslak, Penn State University, arp14@psu.edu \\ D. Scott Hunsinger, Appalachian State University, hunsingerds@appstate.edu
}

\begin{abstract}
The use and frequency of text messaging as a form of communications has grown exponentially over the past decade. Though authors have explored variables that influence acceptance and general use of text messaging, there has been little work done on the frequency and time spent text messaging. In past work we have also examined text messaging but this manuscript attempts to explore more deeply into texting. In 2009 and again in 2016 we examined variables that influence time spent using text messaging as well as how often our subjects text. This study examines variables that affected this quantitative usage in 2009 and compares it to variables influencing in 2016. Statistically significant changes were found over this eight-year time period. This suggests that reasons for technological use may change depending on where the technology is in its life cycle.
\end{abstract}

Keywords: Text Messaging, Longitudinal Research, Theory of Reasoned Action, Theory of Planned Behavior, Technology Acceptance Model, Diffusion of Innovation Theory, End User Computing Satisfaction

\section{INTRODUCTION}

In the United States, texting has become the most common way that $18-49$ year old adults communicate (Newport, 2014). Approximately $97 \%$ of adults in the U.S. send and receive texts each week (Smith, 2015). Texting has grown in popularity with teenagers and college students, with them often texting for over an hour and a half daily (Wood, 2014). Millennials prefer text messages over phone calls, as they are instant and allow them to send quick messages to multiple people at once (Alton, 2017). Texting is the dominant way for many teens to communicate with one another (Lenhart, 2015).

The number of texts sent over the last ten years has soared by more than 7,700\% (Statistic Brain, 2014). In the U.S., over 6 billion texts are sent each day. Worldwide, it has been estimated that more than 560 billion texts are sent every month (Burke, 2016). The latest statistics indicate that around 8 trillion texts are now sent internationally every year (Carducci, 2018). According to Pew Internet, "Text messaging is the most widely-used smartphone feature ...Fully $97 \%$ of smartphone owners used text messaging at least once over the course of the study period, making it the most widely-used basic feature or app" (Smith, 2015). Clearly, the widespread usage of text messaging as a communication technology is worthy of detailed study.

The main purpose of this paper is to examine the variables that influence people to use text messaging as well as how often people text. Our study compares usage of text messaging from a 2009 study and a 2016 study and finds statistically significant changes in several variables influencing texting.

We developed a comprehensive survey to examine all aspects of text messaging usage in 2009 and used the same survey in 2016 to compare the variables that influence text message. Our survey included questions derived from multiple well-known theories including the Theory of Reasoned Action, Technology Acceptance Model, Theory of Planned Behavior, End User Computer Satisfaction, and Diffusion of Innovation.

\section{LITERATURE REVIEW}

Yoon, Jeong, and Rolland (2015) explored how a person's intention to use text messaging is impacted by social influence factors and technical and individual characteristics. They found that approximately $39 \%$ of the variance in behavioral intention is explained by perceived usefulness, perceived enjoyment, perceived critical mass, and 
identification. They also found that $51 \%$ of the variance of perceived usefulness and $38 \%$ of the variance of perceived enjoyment are explained by ease of use, convenience, computer playfulness, personal innovativeness, perceived critical mass, and identification.

Multiple research studies have discovered that females spend more time texting than males (Balakrishnan and Yeow, 2007; Faulkner and Culwin, 2005; Ling, 2003, Reid and Reid, 2004). Balakrishnan and Yeow (2007) looked at the physical aspects of texting and found greater satisfaction in females than males. They reasoned that females may have smaller fingers, which makes it easier and faster for them to press keys than males. Igarashi, Jiro, and Toshikazu (2005) conducted a study on freshmen at a Japanese university and examined gender differences in the usage of text messaging. They found that no differences between males and females in the volume of text messages. The authors noted that females are often more persuaded than men by normative pressures to adopt a technology. (Peslak, Ceccucci, and Sendall (2010) examined text messaging usage and found gender differences in how relative advantage influences their intentions to utilize instant messaging.

Several studies (Burke, 2016; Essany, 2014; Small, 2013) have indicated that text messages have higher response rates and open rates than emails. Since text messages are shorter than most emails, they require less time to read (Burke, 2016). Only one out of every five emails are opened, while approximately $99 \%$ of text messages are opened. Texts are usually read within three minutes and responded to within 90 seconds (Forbes, 2014). Close to half of text messages receive responses, versus a 6\% response rate for emails (Small, 2013).

As of 2018, 98\% of adults 18-29 years old in the United States own a device that is capable of sending and receiving text messages (Dato, 2018). At least one text message per day is sent by 97\% of Americans (Garcia, 2018). Response rates from text messages are 209\% higher than from email, Facebook, or phone calls (Textmarketer, 2018).

\section{THEORIES PROVIDING THE VARIABLES USED IN OUR STUDY}

Several well-known theories provided variables that we used to analyze their influences on text messaging. The Theory of Reasoned Action (Fishbein \& Ajzen, 1975) gave us the Attitude variable, while an extension of the Theory of Reasoned Action (Theory of Planned Behavior) provided a new construct, Perceived Behavioral Control (Ajzen, 1991). From the Technology Acceptance Model (Davis, 1989), we used two variables: Ease of Use and Usefulness. The Diffusion of Innovation Theory (Rogers, 2003) provided the constructs of Compatibility, Complexity, Relative Advantage, and Visibility for our study. In addition, we measured Timeliness, which comes from the End User Computing Satisfaction (Doll and Torkzadeh, 1988). An overview is given in the following sections for each of these theories.

\section{Theory of Reasoned Action}

According to the Theory of Reasoned Action (Fishbein \& Ajzen, 1975), an individual's performance of a specific behavior is determined by his or his/her individual's attitude and his/her subjective norm about the behavior. Figure 1 shows that an individual's intention to perform a specific behavior leads to increased effort and likelihood for the behavior to be actually completed.

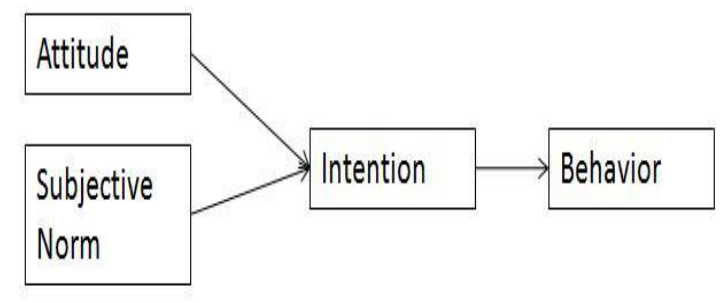

Figure 1. Theory of Reasoned Action

\section{Theory of Planned Behavior}

Figure 2 illustrates the Theory of Planned Behavior. It adds the construct of Perceived Behavioral Control (PBC) to the Theory of Reasoned Action in order to deal with behaviors that are not under full volitional control. Performance 


\section{Issues in Information Systems}

Volume 19, Issue 3, pp. 61-70, 2018

of behaviors that are not under total volitional control may depend on the availability of opportunities and resources such as the cooperation of others, time, money, and skills (Ajzen, 1991).

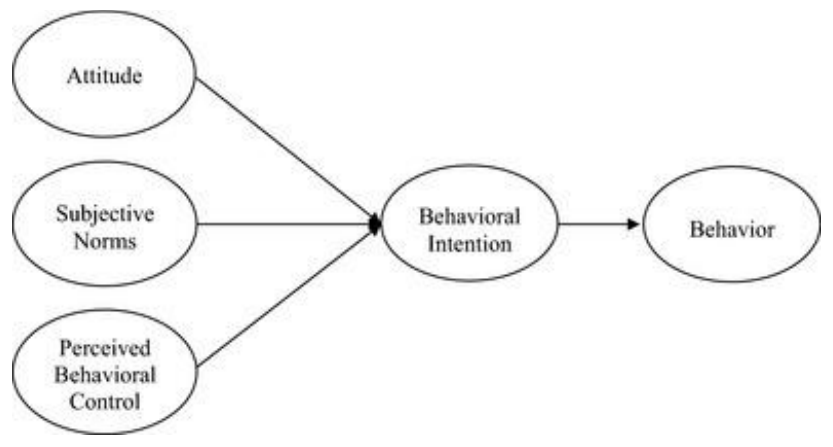

Figure 2. Theory of Planned Behavior

\section{Technology Acceptance Model}

The Technology Acceptance Model, shown in Figure 3, uses Perceived Usefulness and Perceived Ease of Use to predict an individual's willingness to adopt technology. Perceived Usefulness is defined as "the degree to which a person believes that using a particular system would enhance his or her job performance." Perceived Ease of Use is defined as "the degree to which a person believes that using a particular system would be free of effort" (Davis, 1989).

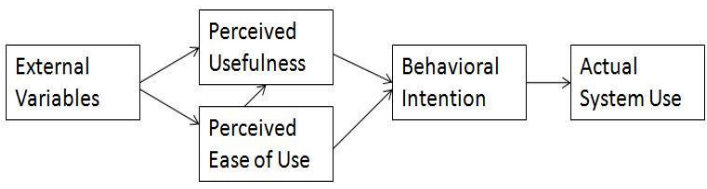

Figure 3. Technology Acceptance Model

\section{Diffusion of Innovation Theory}

The Diffusion of Innovation theory examines how, why, and how quickly new ideas and technology spread (Rogers, 1962; Rogers, 2003). Rogers (2003) identified five major factors that impact the rate of adoption: Compatibility complexity, relative advantage, trialability, and observability or visibility.

The adoption of an innovation or technology follows an $\mathrm{S}$ curve when it is plotted over a period of time (Fisher, 1971). Critical mass occurs when enough people have adopted the innovation and its rate of adoption becomes selfsustaining (Rogers, 2003).

As shown in Figure 4, adopters are grouped into into five categories:

1) Innovators,

2) Early Adopters,

3) Early Majority,

4) Late Majority,

5) Laggards. 


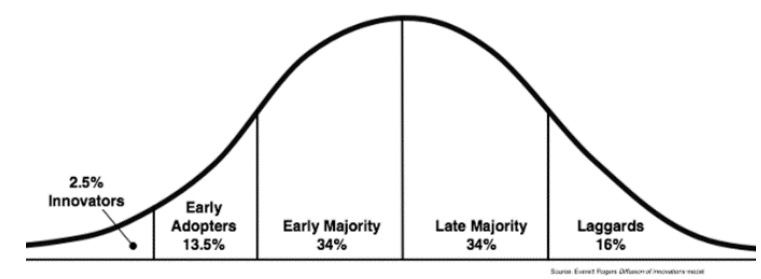

Figure 4. Diffusion of Innovation

\section{End User Computing Satisfaction}

The End User Computing Satisfaction model uses five factors: Content, Accuracy, Format, Ease of Use, and Timeliness. Doll and Torkzadeh (1988) created an instrument to measure these five components. Figure 5 shows the five factors that may influence end user computing satisfaction.

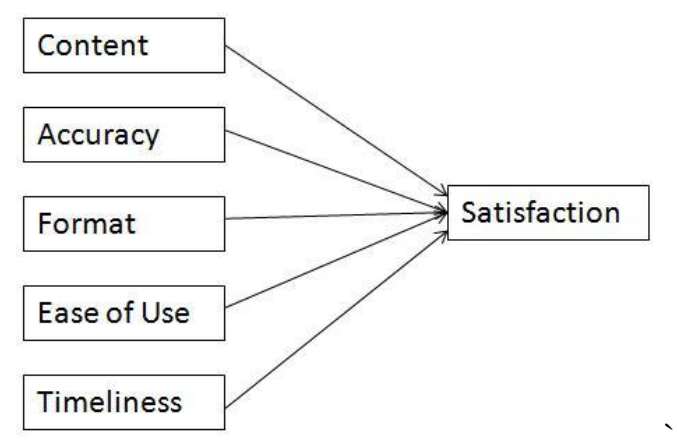

Figure 5. End User Computing Satisfaction

\section{METHODOLOGY}

Methodology has been described in prior studies as follows (Peslak, Hunsinger, \& Kruck, 2017). A comprehensive survey was developed to explore all aspects of text messaging usage in 2009. The survey included key questions used in the development of past studies of Theory of Reasoned Action, Technology Acceptance Model, Theory of Planned Behavior, End User Computer Satisfaction, and Diffusion of Innovation. The same survey was used for 2016. Table 1 shows the variables and questions that were used in this study. Our primary research goal was to determine how various variables associated with technology adoption changed with regard to text messaging from 2009 to 2016. One key question was selected for each variable. This survey was administered in 2009 to students and other University personnel at two Northeastern Universities. Results were published as a result of this survey (blinded). The exact same survey was repeated in 2016 to see if attitudes towards text messaging had changed over time. The study this time was administered at three Northeastern Universities and though the same subjects were not available for the 2016 study, they were drawn from the same demographic pool as the 2009 study. All questions were scaled from 1 to 7 with 1 being Strongly Disagree and 7 being Strongly Agree. Four was a Neutral view. All the questions except the one used to measure Complexity were positive questions (good, pleased, compatible) so the higher the score the higher the favorability toward text messaging. By having all scaled similarly, relative comparisons could be made across all variables. The one exception to positive questions was Complexity in Diffusion of Innovation Theory, Text messaging requires a lot of mental effort which is a negative question. 
Table 1. Variable Models and References

\begin{tabular}{|l|l|l|}
\hline \multicolumn{1}{|c|}{ Variable } & \multicolumn{1}{|c|}{ Actual survey question } & \multicolumn{1}{c|}{ Model } \\
\hline Attitude & Text messaging is good. & Theory of Reasoned Action/TPB \\
\hline Critical Mass & $\begin{array}{l}\text { Many people I know will continue to use } \\
\text { Text messaging. }\end{array}$ & Diffusion of Innovation \\
\hline Usefulness & I find Text messaging useful. & Technology Acceptance Model/ECT \\
\hline Complexity & $\begin{array}{l}\text { Text messaging requires a lot of mental } \\
\text { effort. }\end{array}$ & Diffusion of Innovation \\
\hline Compatibility & $\begin{array}{l}\text { Text messaging is compatible with how I } \\
\text { communicate. }\end{array}$ & Diffusion of Innovation \\
\hline Ease of Use & Text messaging is easy to do. & Technology Acceptance Model /EUCS \\
\hline Relative Advantage & $\begin{array}{l}\text { Text messaging improves my } \\
\text { productivity. }\end{array}$ & Diffusion of Innovation \\
\hline Perceived Behavioral Control & $\begin{array}{l}\text { Text messaging is entirely within my } \\
\text { control. }\end{array}$ & Theory of Planned Behavior \\
\hline Timeliness & $\begin{array}{l}\text { Text messaging provides needed } \\
\text { information quickly. }\end{array}$ & End User Computer Satisfaction \\
\hline Visibility & I have seen many people Text messaging. & Diffusion of Innovation \\
\hline
\end{tabular}

The statistical analyses were based on a sample of 153 valid surveys in 2009 and 162 valid surveys in 2016. Since the surveys were collected in classes, response rate was near 100\%. The 2009 survey however included a strong mix of faculty and other professionals. In order to properly compare 2009 with 2016, only self-identified students were included in the survey analysis. This resulted in 72 respondents from 2009 and 141 from 2016. The gender mix was higher in females in 2009 versus 2016 as shown in table 1. A prior study (Peslak, Ceccucci, and Sendall, 2010)) however found no significant difference between females and males in all these variables except emotions. Most students in both 2009 and 2016 were in the 18-24 age bracket. We propose the sample has a comparable mix of gender and age.

Our prior manuscript only studied whether the variables shown in Table 1 significantly changed from 2009 to 2016. In this study, we use the variables in table 1 and via multiple regression analysis determine which factors significantly influence time and frequency of text messaging usage. The dependent variables used were time spent texting and frequency of texting. The independent variables used were the results of the survey shown in table 1.

\section{RESULTS}

Table 2 presents the results of multiple regression analysis using how often you use text messaging as the dependent variable and the adoption variables from Table 1 as the independent variables. The Adjusted R square was .298 but was significant at $\mathrm{p}<.001$. Results from 2009 show four significant variables at $\mathrm{p}<.10$. These variables are Useful, requiring a lot of mental effort (reverse correlation), control, seen many people using. This supports that there were many variables affecting text messaging in 2009. 
Table 2. 2009 Regression Analysis Frequency of Use

\begin{tabular}{|c|c|c|c|c|c|c|}
\hline \multirow{2}{*}{\multicolumn{2}{|c|}{ Model }} & \multicolumn{2}{|c|}{ Unstandardized Coefficients } & \multirow{2}{*}{\begin{tabular}{|l}
$\begin{array}{l}\text { Standardized } \\
\text { Coefficients }\end{array}$ \\
Beta \\
\end{tabular}} & \multirow{3}{*}{\begin{tabular}{|l}
$\mathbf{t}$ \\
4.684
\end{tabular}} & \multirow{3}{*}{\begin{tabular}{|l} 
Sig. \\
.000
\end{tabular}} \\
\hline & & \multirow{2}{*}{$\begin{array}{l}\text { B } \\
5.437\end{array}$} & \multirow{2}{*}{\begin{tabular}{|l} 
Std. Error \\
1.161
\end{tabular}} & & & \\
\hline 1 & (Constant) & & & & & \\
\hline & Attitude & -.008 & .195 & -.007 & -.039 & .969 \\
\hline & Critical Mass & .058 & .190 & .061 & .303 & .763 \\
\hline & Usefulness & -.529 & .267 & -.499 & -1.984 & .050 \\
\hline & Complexity & .247 & .140 & .221 & 1.769 & .080 \\
\hline & Compatibility & -.140 & .122 & -.120 & -1.145 & .255 \\
\hline & Ease of Use & -.434 & .179 & -.377 & -2.425 & .017 \\
\hline & Relative Advantage & -.046 & .142 & -.036 & -.322 & .748 \\
\hline & Perceived Behavioral Control & .290 & .154 & .253 & 1.874 & .064 \\
\hline & Timeliness & .132 & .243 & .118 & .544 & .588 \\
\hline & Visibility & .466 & .211 & .460 & 2.209 & .030 \\
\hline
\end{tabular}

a. Dependent Variable: howoften

b. Selecting only cases for which $2009=1$

Table 3 presents the results of multiple regression analysis using How often you use text messaging as the dependent variable and the adoption variables from table 1 as the independent variables. The Adjusted $R$ square was .272 but was significant at $\mathrm{p}<.001$. Results from 2016 show one significant variable at $\mathrm{p}<.10$. This variable is usefulness. This supports that there were many variables affecting text messaging in 2009. This suggests that difficulty and critical mass and control have ceased to be important for this more mature technology in 2016.

Table 3. 2016 Regression Analysis Frequency of Use

\begin{tabular}{|c|c|c|c|c|c|c|}
\hline \multirow{2}{*}{\multicolumn{2}{|c|}{ Model }} & \multicolumn{2}{|c|}{ Unstandardized Coefficients } & \multirow{2}{*}{$\begin{array}{l}\text { Standardized Coefficients } \\
\text { Beta }\end{array}$} & \multirow[b]{2}{*}{$\mathbf{t}$} & \multirow[b]{2}{*}{ Sig. } \\
\hline & & B & Std. Error & & & \\
\hline \multirow[t]{11}{*}{1} & (Constant) & 7.659 & .405 & & 18.900 & .000 \\
\hline & Attitude & .060 & .067 & .080 & .903 & .368 \\
\hline & Critical Mass & -.125 & .110 & -.116 & -1.141 & .256 \\
\hline & Usefulness & -.240 & .108 & -.319 & -2.221 & .028 \\
\hline & Complexity & -.027 & .049 & -.046 & -.540 & .590 \\
\hline & Compatibility & -.006 & .047 & -.011 & -.132 & .895 \\
\hline & Ease of Use & -.028 & .082 & -.036 & -.340 & .734 \\
\hline & Relative Advantage & -.013 & .042 & -.026 & -.318 & .751 \\
\hline & Perceived Behavioral Control & -.023 & .061 & -.036 & -.386 & .700 \\
\hline & Timeliness & -.057 & .075 & -.081 & -.762 & .448 \\
\hline & Visibility & -.066 & .085 & -.090 & -.784 & .434 \\
\hline
\end{tabular}

a. Dependent Variable: howoften

b. Selecting only cases for which $2016=2$

There were different results when the dependent variable was changed to time spent text messaging. The 2009 Adjusted R square was .290 but was significant at $\mathrm{p}<.001$.Ease of use and mental effort (reverse) were again significant in 2009 but usefulness was not. Longer messages did not equate to more usefulness. In 2016, ease of use remains as a significant variable but increasing productivity is now added as a significant variable at $\mathrm{p}<.10$. The Model Adjusted R square was only .116 but was significant at $\mathrm{p}<.004$. Users appear to have discovered the benefits of productivity gains through longer text messaging. It still needs to be easy for time spent text messaging. 
Table 4. 2009 Regression Analysis Time Spent Text Messaging

\begin{tabular}{|l|l|l|l|l|l|l|}
\hline \multirow{2}{*}{ Model } & \multicolumn{2}{l|}{ Unstandardized Coefficients } & Standardized Coefficients & & \\
\cline { 2 - 7 } & $\mathrm{B}$ & Std. Error & Beta & $\mathrm{t}$ & Sig. \\
\hline 1 & 3.539 & .933 & & 3.794 & .000 \\
\cline { 2 - 7 } & Constant) & -.019 & .157 & -.022 & -.119 & .905 \\
\hline Attitude & .219 & .153 & .289 & 1.431 & .156 \\
\hline Critical Mass & -.033 & .214 & -.038 & -.152 & .880 \\
\hline Usefulness & .230 & .112 & .257 & 2.051 & .043 \\
\hline Complexity & -.059 & .098 & -.063 & -.599 & .551 \\
\hline Compatibility & -.390 & .144 & -.424 & -2.712 & .008 \\
\hline Ease of Use & -.044 & .115 & -.044 & -.382 & .703 \\
\hline Relative Advantage & -.092 & .124 & -.100 & -.739 & .462 \\
\hline Perceived Behavioral Control & -.165 & .195 & -.184 & -.848 & .398 \\
\hline Timeliness & .279 & .170 & .344 & 1.642 & .104 \\
\hline
\end{tabular}

a. Dependent Variable: time

b. Selecting only cases for which $2009=1$

Table 5. 2016 Regression Analysis Time Spent Text Messaging

\begin{tabular}{|c|c|c|c|c|c|c|}
\hline \multirow{2}{*}{\multicolumn{2}{|c|}{ Model }} & \multicolumn{2}{|c|}{ Unstandardized Coefficients } & \multirow{2}{*}{$\begin{array}{l}\text { Standardized Coefficients } \\
\text { Beta }\end{array}$} & \multirow[b]{2}{*}{$\mathbf{t}$} & \multirow[b]{2}{*}{ Sig. } \\
\hline & & B & Std. Error & & & \\
\hline \multirow[t]{11}{*}{1} & (Constant) & 5.849 & .682 & & 8.576 & .000 \\
\hline & Attitude & -.070 & .113 & -.058 & -.620 & .536 \\
\hline & Critical Mass & -.031 & .185 & -.018 & -.169 & .866 \\
\hline & Usefulness & -.249 & .183 & -.210 & -1.363 & .175 \\
\hline & Complexity & -.048 & .083 & -.052 & -.572 & .568 \\
\hline & Compatibility & -.039 & .079 & -.044 & -.498 & .620 \\
\hline & Ease of Use & -.327 & .140 & -.265 & -2.337 & .021 \\
\hline & Relative Advantage & .133 & .071 & .163 & 1.868 & .064 \\
\hline & Perceived Behavioral Control & -.050 & .102 & -.049 & -.488 & .626 \\
\hline & Timeliness & -.049 & .126 & -.044 & -.389 & .698 \\
\hline & Visibility & .127 & .145 & .110 & .875 & .383 \\
\hline
\end{tabular}

a. Dependent Variable: time

b. Selecting only cases for which $2016=2$

Testing was performed for multicollinearity among independent varaibles. According to Olague, Etzkorn, Gholston, \& Quattlebaum (2007) "There is no "industry standard" VIF threshold value established. In general, in OLS regression, a variable whose VIF value is greater than 10 may indicate possible multicollinearity problems and should be investigated further." A complete SPSS testing of all ten independent variables was performed and no VIF factor exceeded the threshold. Therefore, we found no collinearity issues.

\section{DISCUSSION}

Gao et al. (2013) note that the technology life cycle consists of four phases, emerging, growth, maturity, and saturation. Text messaging has been progressing through these phases between 2009 and 2016. We suggest that in 2009 text messaging was still in a growth stage whereas in 2016 we have reached a maturity phase. As a result, we postulate that the different variables we found influencing text messaging in 2009 versus 2016 are due to this maturation of the text messaging technology. Results from 2009 show four significant variables at $\mathrm{p}<.10$ usefulness, requiring a lot of mental effort (reverse correlation), control, and seen many people using (critical mass). In the growth phase, the number of people using spurred more usage as we wanted to communicate with others who had adopted the technology. Ease of use was also important since it was a new form of communication that had to be learned. The easier the learning curve, the more adoption. Control was important due to potential privacy risks 
that may be associated with any form of communication. The privacy risks seen were from providers, other users, and malicious hackers. Finally, usefulness was considered important. Those who recognized the usefulness of the technology used it more and more often. As noted, there was a small difference in the variables in 2009. The four above mentioned significantly affected frequency of texting. For time spent texting, control and critical mass were not a significant variable. In 2016, the variables influencing time spent have changed. Since we see text messaging transitioning to a more mature life cycle phase, only usefulness is a significant variable. Ease of use, control, and critical mass are no longer significant variables. Since it is an established technology with a critical mass, strong control, and relative ease of use, frequency of use are not affected by these variables. Finally, though time spent is still affected by ease of use and complexity (requiring a lot of mental effort, score reversed). This suggests that those who find texting more difficult or clumsy seem to have shorter messages and/or less messages.

\section{CONCLUSION}

An important finding of our work is that different variables may affect technology usage depending on the phase of the technology life cycle to which they have evolved. This is an important finding that suggests further study and may have much broader implications for all technology adoption. Another potential area of expanded research is to develop more survey questions per independent variable to perform confirmatory factor analysis and potential structural equation modeling.

\section{REFERENCES}

Ajzen, I. \& Fishbein, M. (1980). Understanding Attitudes and Predicting Social Behavior. Englewood Cliffs: Prentice-Hall, Inc.

Alton, L. (2017). Phone Calls, Texts or Email? Here's How Millennials Prefer To Communicate. https://www.forbes.com/sites/larryalton/2017/05/11/how-do-millennials-prefer-tocommunicate/\#2ecfb5ba6d6f.

Balakrishnan, V. \& Yeow, P. (2007). Texting satisfaction: does age and gender make a difference? International Journal of Computer Science and Security, 1(1), 85-96.

Burke, Kenneth. How Many Texts Do People Send Every Day? May 18, 2016. https://www.textrequest.com/blog/many-texts-people-send-per-day/

Burke, Kenneth. Is Our Mobile Dependence Actually a Bad Thing? Here's the Research. October 27, 2015. https://www.textrequest.com/blog/is-mobile-dependence-actually-a-bad-thing/

Cardacci, A. (2018). State of Text Messaging Around the World in 2018. https://blog.textrecruit.com/state-oftexting-around-the-world-in-2018.

Dato, N. (2018). "7 Essential Text Messaging Stats Every Business Owner Should Know." http://customerthink.com/7-essential-text-messaging-stats-every-business-owner-should-know/.

Davis, F. D. (1989). Perceived Usefulness, Perceived Ease of Use, and User Acceptance of Information Technology. MIS Quarterly, 13(3), 319-340. 9.

Doll, W., \& Torkzadeh, G. (1988). The Measurement of End-User Computing Satisfaction. MIS Quarterly, 12(6), 259-274.

Essany, M. SMS Marketing Wallops Email with 98\% Open Rate and Only 1\% Spam.Mobile Marketing Watch. https://mobilemarketingwatch.com/sms-marketing-wallops-email-with-98-open-rate-and-only-1-spam43866/ August 6, 2014. 
Faulkner, X. \& Culwin, F. (2005). When Fingers Do The Talking: A Study of Text Messaging. Interacting with Computers, 17, 167-185.

Fishbein, M., \& Ajzen, I. (1975). Belief, Attitude, Intention, and Behavior: An Introduction to Theory and Research. Reading, MA: Addison-Wesley.

Fisher, J.C. (1971). A simple substitution model of technological change. Technological Forecasting and Social Change. 3, 75-88.

Garcia, Z. (2018). Text messaging stats that matter. https://www.chromis.com/text-stats-that-matter/.

Gao, L., Porter, A. L., Wang, J., Fang, S., Zhang, X., Ma, T., ... \& Huang, L. (2013). Technology life cycle analysis method based on patent documents. Technological Forecasting and Social Change, 80(3), 398-407.

Igarashi, T., Jiro, T., \& Toshikazu, Y. (2005). Gender differences in social network development via mobile phone messages: a longitudinal study. Journal of Social and Personal Relationships, 22(5), 591-713.

Lenhart, A. (2015). Teens, Technology and Friendships; Video games, social media and mobile phones play an integral role in how teens meet and interact with friends. http://www.pewinternet.org/2015/08/06/teenstechnology-and-friendships/

Ling, R. (2003). The Socio-linguistic of SMS: An Analysis of SMS Use by a Random Sample of Norwegians. Mobile Communications: Renegotiation of the Social Sphere, Ling, R. and Pedersen, P. (Eds.), pp. 335 349 (London: Springer, 2003).

Newport, Frank. The New Era of Communication among Americans. November 10, 2014. http://www.gallup.com/poll/179288/new-era-communication-americans.aspx.

Olague, H. M., Etzkorn, L. H., Gholston, S., \& Quattlebaum, S. (2007). Empirical validation of three software metrics suites to predict fault-proneness of object-oriented classes developed using highly iterative or agile software development processes. IEEE Transactions on software Engineering, 33(6), 402-419.

Peslak, A., Ceccucci, W., \& Sendall, P. (2010). An Empirical Study of Instant Messaging Behavior Using Diffusion of Innovation Theory, Journal of Information Systems Applied Research, 3(18), 3-13.

Peslak, A. Hunsinger, D. S., \& Kruck, S. E. (2017) Text Messaging Today: A Longitudinal Study of Variables Influencing Text Messaging from 2009 to 2016, 2017 Proceedings of the Conference on Information Systems Applied Research, Austin, TX.

Reid, F. J. M. \& Reid, D. J., (2004). Text Appeal: The Psychology of SMS Texting and Its Implications for the Design of Mobile Phone Interfaces. Campus Wide Information Systems, 21, 196-200.

Rogers, Everett M. (1962). Diffusion of Innovations (1st ed.). New York: Free Press of Glencoe.

Rogers, Everett (2003). Diffusion of Innovations, 5th Edition. Simon and Schuster.

Small, Adam. How to Use SMS to Win Love, Leads, Revenue. https://martech.zone/text-messaging/ March 5, 2013.

Smith, Aaron. U.S. Smartphone Use in 2015. http://www.pewinternet.org/2015/04/01/us-smartphone-use-in-2015/ April 1, 2015.

Statistic Brain Research Institute (2014). "Text Message Statistics." http://www.statisticbrain.com/text-messagestatistics/ 


\section{Issues in Information Systems}

Volume 19, Issue 3, pp. 61-70, 2018

Text Marketer (2018). https://www.textmarketer.co.uk/blog/2018/01/business-sms/9-of-the-biggest-must-readmarketing-stats-for-2018/.

Wood, Janice. College Students in Study Spend 8 to 10 Hours Daily on Cell Phone. https://psychcentral.com/news/2014/08/31/new-study-finds-cell-phone-addiction-increasingly-realisticpossibility/74312.html

Yoon, C., Jeong, C. \& Rolland, E. (2015). Understanding individual adoption of mobile instant messaging: a multiple perspectives approach. Information Technology and Management, 16(2), 139-151. 